\title{
SHORT COMMUNICATIONS КРАТКИЕ СООБЩЕНИЯ \\ ROAD-KILLED GROUND BEETLES PROVE THE PRESENCE OF CARABUS HUNGARICUS (COLEOPTERA: CARABIDAE) IN NORTH-WESTERN ROMANIA
}

\author{
Alfred Ș. Cicort-Lucaciu \\ University of Oradea, Romania \\ e-mail: cicort.alfred@yahoo.com
}

Received: 10.01.2020. Revised: 30.06.2020. Accepted: 11.07.2020.

\begin{abstract}
Carei Plain is a Protected Area in Northwestern Romania with a rich biodiversity, which among other human impacts, is threatened by road traffic. The road mortality intensity and its consequences were indicated in the region by some studies. During such a road mortality survey, realised in 2016, we identified five road-killed individuals of Carabus hungaricus, a rare species in Romania. Carei Plain is situated a few kilometres away from the area where the species presence was known in Hungary. The road is surrounded with sand dunes and wet areas with rich herbaceous vegetation, but also with Robinia pseudoacacia plantations. Carabus hungaricus is a rare species, with zoogeographic and conservation importance, affected by the road mortality in the region. The real distribution of $C$. hungaricus in the region should be established by investigating its potential habitats in the Protected Area.
\end{abstract}

Key words: Carei Plain, distribution, grassland, habitat, Protected Area, road mortality

\section{Introduction}

Temperate grasslands are one of the most affected and threatened ecosystems (Henwood, 2010). The strong disturbance of their surviving biodiversity caused by future human activities was already predicted (Sala et al., 2000). A recent study indicated that a dramatic decline of the open grassland habitats will take place in the future in the case of Deliblato Sands (Ivajnšič \& Devetak, 2020). A species directly threatened by agricultural activities on steppes is Carabus hungaricus Fabricius, 1792 (Turin et al., 2003). It is a beetle species with Eurasian distribution recorded from Austria to Kazakhstan (Kadyrbekov et al., 2016; Březina et al., 2017). Its current distribution area is fragmented by the Romanian Plain (Turin et al., 2003). In Romania, C. hungaricus is a rare species (Barloy \& Prunar, 2012a), with only two reliable records. One of them is located in western Romania, between Jamu Mare and Lățunaș localities (Lie, 1995, 1996), while the other is situated in southern Romania, near Murta locality (Popescu \& Iorgu, 2016). Other records are either out of date and unconfirmed (Breuning, 1932), or only mentioned in the standard data form of some Natura 2000 sites and not supported by any, previously or subsequently published, study (Barloy \& Prunar, 2012a,b). In the vicinity of Romania, $C$. hungaricus was recorded in Ömböly in Hungary (Szél et al., 2006), Deliblato in Serbia (Breuning, 1932),
Dragoman in Bulgaria (Hieke \& Wrase, 1988; Geuorguiev \& Geuorguiev, 1995), Codru Reserve in Moldova (Baban, 2015) and Khotyn National Park in Ukraine (Putchkov, 2009). In Bulgaria, there are other new records of $C$. hungaricus (Bekchiev et al., 2018). Probably, because it uses open habitats, C. hungaricus seems faster compared with other carabid species (Bérces \& Růžičková, 2019). Generally, the movement of C. hungaricus individuals seems random, but their speed differs among the utilised habitat types (Bérces \& Růžičková, 2019). When the habitats of ground beetles are crossed by roads, they can fall victims to vehicles (e.g., Noordijk et al., 2006; Yamada et al., 2010; Cicort-Lucaciu et al., 2016). Knowing the facts that the Carei Plain fauna is affected by road mortality (Cicort-Lucaciu et al., 2012; Covaciu-Marcov et al., 2017), and $C$. hungaricus is present in the immediate vicinity in Hungary (Szél et al., 2006), we hypothesised that the species could also be present in the region and its presence could be indicated by road mortality. Recently in Carei Plain road mortality revealed the existence of some species whose presence was not known previously in the region (Teodor et al., 2019). This fact is true for other animal groups in another region in Romania (Covaciu-Marcov et al., 2012, 2020). In this context, our objective was to search also for road-killed $C$. hungaricus individuals during the road mortality study in Carei Plain. 


\section{Material and Methods}

The study was made in 2016 in Carei Plain Protected Area, Northwestern Romania (Fig. 1). We studied the road mortality of fauna on a recently modernised road, situated between Sanislău and Horia localities. The mortality on this road was already studied before its modernisation (CicortLucaciu et al., 2012). Thus, our main objective was to observe how road mortality increased after road modernisation. The studied road was monitored on its entire length once every two weeks, between March and October (unpublished data). We made pedestrian surveys on the road, like in other similar studies (Cicort-Lucaciu et al., 2012, 2016; CovaciuMarcov et al., 2017). During those pedestrian surveys, we collected some road-killed ground-beetles, like in the case of other road-killed insects (Teodor et al., 2019). The identification of road-killed ground beetles from Carei Plain was realised in the laboratory following the keys (e.g. Breuning, 1932).

\section{Results}

In 2016, we identified a new population of $C$. hungaricus in Northwestern Romania (Fig. 1), between Sanislău and Horea localities. Totally, we encountered five road-killed $C$. hungaricus individuals. The first individual was identified on 26 May 2016. On 8 June 2016, we encountered another three individuals, and on 23 June 2016, another one. The road-killed ground beetles were identified in sectors where the road is surrounded both by sandy areas, wet areas, and Robinia pseudoacacia L. plantations. Three $C$. hungaricus corpses were relatively unbroken (Fig. 2), one was partially dismantled, and the last one was in an advanced state of degradation. The identification realised using the keys of Breuning (1932) proved that the encountered individuals belong to $C$. hungaricus hungaricus Fabricius, 1792 (Fig. 2).

\section{Discussion}

Despite the existence of some data upon ground beetles in Carei Plain, C. hungaricus had not previously been mentioned in the region (Ardelean \& Karácsonyi, 2005). Nevertheless, C. hungaricus presence in Northwestern Romania was expectable due to the short distance to the country border with Hungary and to its currently known distribution range (Szél et al., 2006). The other two recently recorded populations in Romania are situated either in south-western Romania, in Banat region (Lie, 1995, 1996), or even further south, beyond the Carpathian Mountains, in Oltenia region (Popescu \& Iorgu, 2016).

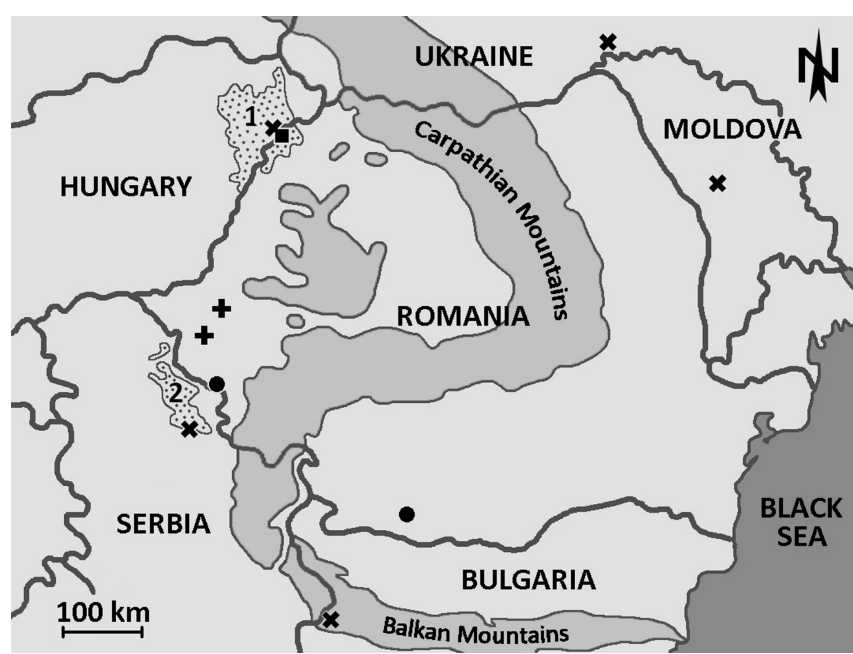

Fig. 1. The distribution of Carabus hungaricus in Romania. Designations: square - new record, circle - other recent and reliable records, cross - old records from Breuning, $\mathrm{x}$ - the closest records from the surrounding countries, 1 - Nyirség and Nirului Plain, 2 - Deliblato Sands.

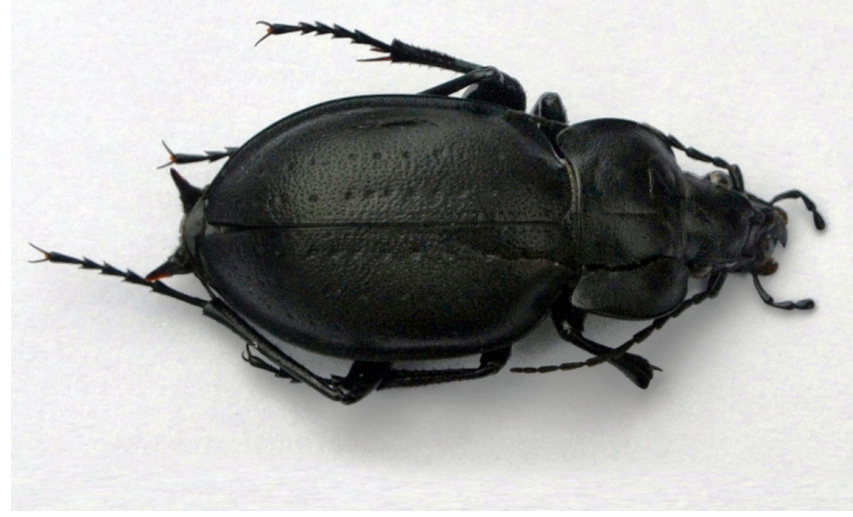

Fig. 2. The road-killed Carabus hungaricus hungaricus from Northwestern Romania.

Near the road where we encountered the roadkilled $C$. hungaricus individuals, there were sand dunes with herbaceous vegetation, Robinia pseudoacacia plantations on sand dunes and wet areas with rich herbaceous vegetation. The species was found near two $R$. pseudoacacia plantations crossed by the road. Near plantations psammophile grassland fragments are still preserved, vegetation which once dominated the nearby sandy oak woods and interdune marshes (Boros, 1932). We consider that these fragments represent, in fact, the species' main habitat, which prefers more humid areas of the steppe, with higher herbaceous vegetations, completely avoiding dense forest (Cizek et al., 2012; Pokluda et al., 2012). With all its preference toward natural habitats, $C$. hungaricus was also mentioned in urban areas (Putchkov et al., 2019). The identification of road-killed C. hungaricus individuals in late May and especially in June corresponds with one of this species' activity peaks (Bérces \& Elek, 2013). 
As a steppe species (Panin, 1955), C. hungaricus lives in Hungary on calcareous sandy grasslands near the River Danube and River Tisa, on dolomitic grasslands from Buda and Bakony Mountains, and on acidic grasslands from the Nyirség area (Szél et al., 2006). The sandy areas from Northwestern Romania, known as Nirului Plain, are continuous with the Nyirség area (Hungary). Therefore, many species mentioned on the sand dunes from Nyirség were also recorded in Nirului Plain (e.g. Covaciu-Marcov et al., 2009; Sas-Kovács et al., 2015). It is considered that some of the thermophilous steppe species have arrived in the Great Hungarian Plain through the Lower Danube Corridor (Magyari et al., 2010). Probably, the psammophilous species have advanced along the River Danube and River Tisa up to the sand dunes situated at the Hungarian-Romanian border (Covaciu-Marcov et al., 2009). Nevertheless, in the region, wet areas shelter the ancient fauna and flora (e.g. Covaciu-Marcov et al., 2009; Ferenți et al., 2012; Szatmari, 2015). Thus, even being a steppe element, $C$. hungaricus preferences for more humid areas of the steppe (Cizek et al., 2012; Pokluda et al., 2012) probably place this species in this category.

Recent studies have indicated that road-killed animals could provide ecological or zoogeographic information (e.g. Teodor et al., 2019; Ile et al., 2020). Road-killed C. hungaricus records in Northwestern Romania confirm this fact. Although the number of road-killed ground beetles was low, the main activity peak of $C$. hungaricus is in autumn (Bérces \& Elek, 2013), and we only determined individuals that were killed in summer. At the same time, even if roads act as barriers for forest ground beetles (Yamada et al., 2010), C. hungaricus is a steppe species (Panin, 1955). It seems to be more vulnerable to road mortality compared to other ground beetles. Nevertheless, the barrier effect of roads was mentioned also in the case of ground beetle species with other ecological demands (Noordijk et al., 2006).

The Nirului Plain is a part of the Protected Area of the community interest «Carei Plain». Thus the presence of this species increases its conservation importance. The discovery of this species in Carei Plain shows the necessity of studies on its distribution. It should be searched in different habitat types in the region using adequate methods. At the same time, investigating other roads from the region, or the same road but on a longer period would make possible investigations on the species activity cycle, which has two peaks (Bérces \& Elek, 2013). Thus, studying road-killed animals proves its value one more time, succeeding to offer information without any impact on living specimens, a fact recently indicated in Romania in the case of other animals (Ile et al., 2020). Regarding the impact of roads on biodiversity in the Carei Plain, we consider that the most important conservation decision should be to stop further road modernisation in the region.

\section{Acknowledgements}

Our study was realised with the support of Freies Europa Weltanschauung Fundation, the former custodian of the Carei Plain Natural Protected Area, which we wish to thank in this way.

\section{References}

Ardelean G., Karácsonyi K. 2005. Flora, vegetația, fauna și ecologia nisipurilor din nord-vestul României. Satu Mare: Daya. 732 p.

Baban E. 2015. Carabus hungaricus (Fabricius 1792), carabidă-ungarică. In: G. Duca (Ed.): The Red Book of the Republic of Moldova. Chișinău: Știința. P. 30.

Barloy J., Prunar F. 2012a. Contributions to the knowledge of the rare or localized species distribution from the Carabus genre in Romania. Research Journal of Agricultural Science 44(2): 164-171.

Barloy J., Prunar F. 2012b. Considerations on the genus Carabus species protected in Romania by the Natura 2000 network. Research Journal of Agricultural Science 44(2): 151-163.

Bekchiev R., Guéorguiev B., Kostova R., Chehlarov E., Sivilov O. 2018. New records of rare and threatened beetles (Insecta: Coleoptera) in Bulgaria. Acta Zoologica Bulgarica 70(4): 501-506.

Bérces S., Elek Z. 2013. Overlapping generations can balance the fluctuations in the activity patterns of an endangered ground beetle species: long term monitoring of Carabus hungaricus in Hungary. Insect Conservation and Diversity 6(3): 290-299. DOI: 10.1111/j.17524598.2012.00218.x

Bérces S., Růžičková J. 2019. Habitat use of an endangered beetle Carabus hungaricus assessed via radio telemetry. Acta Zoologica Academiae Scientiarum Hungaricae 65(4): 335-348. DOI: 10.17109/AZH.65.4.335.2019

Boros A. 1932. Die Flora und die Pflanzengeographischen Verhältnisse des Nyirség's (Vegetation). In: A. Boros (Ed.): A Nyirség flórája és növényföldrajza. Budapest: Magyar Tudományos Akadémia. P. 133-177.

Breuning S. 1932. Monographie der Gattung Carabus L. Bestimmungs-Tabellen der europäischen Coleopteren. Troppau: Verlag Edmund Reitter's Nachfolger Emmerich Reitter. 1610 p.

Březina B., Huber C., Marggi W. 2017. Subtribe Carabina Latreille, 1802. In: I. Löbl, D. Löbl (Eds.): Catalogue of Palaearctic Coleoptera. Revised and Updated Revision. 
Vol. 1. Archostemata-Myxophaga-Adephaga. LiedenBoston: Brill. P. 70-207.

Cicort-Lucaciu A.Ș., Covaciu-Marcov S.D., Bogdan H.V., Sas I. 2012. Implication upon Herpetofauna of a Road and its Reconstruction in Carei Plain Natural Protected Area (Romania). Ecologia Balkanica 4(1): 99-105.

Cicort-Lucaciu A.Ș., Sas-Kovács I., Covaciu-Marcov S.D. 2016. Non road human influence upon road mortality on three secondary roads in the Vâlsan River protected area, Romania. Oltenia, Studii și Comunicări, Științele Naturii 32(2): 99-106.

Cizek L., Hauck D., Pokluda P. 2012. Contrasting needs of grassland dwellers: habitat preferences of endangered steppe beetles (Coleoptera). Journal of Insect Conservation 16(2): 281-293. DOI: 10.1007/s10841-011-9415-6

Covaciu-Marcov S.D., Sas I., Cicort-Lucaciu A.Ș., Kovács É.H., Pintea C. 2009. Herpetofauna of the natural reserves from Carei Plain: zoogeographical significance, ecology, statute and conservation. Carpathian Journal of Earth and Environmental Sciences 4(1): 69-80.

Covaciu-Marcov S.D., Ferenți S., Cicort-Lucaciu A.Ș., Sas I. 2012. Eryx jaculus (Reptilia, Boidae) north of Danube: a road-killed specimen from Romania. Acta Herpetologica 7(1): 41-47.

Covaciu-Marcov S.D., Puskás A., Pop A.N., Țârţ M., Ferenți S. 2017. Road-killed amphibians and reptiles on a local road in a protected area in western Romania. Acta Zoologica Bulgarica 69(1): 115-120.

Covaciu-Marcov S.D., Cicort-Lucaciu A.S,., Pop D.R., Lucaci B.I., Ferenți S. 2020. More road-killed Caspian Whipsnakes (Dolichophis caspius): an update on the species distribution along the Danube in Romania. Amphibian and Reptile Conservation 14(1): 183-189.

Ferenți S., Cupşa D., Covaciu-Marcov S.D. 2012. Ecological and zoogeographical significance of terrestrial isopods from the Carei Plain natural reserve (Romania). Archives of Biological Sciences 64(3): 1029-1036. DOI: 10.2298/ABS1203029F

Geuorguiev V.B., Geuorguiev B.V. 1995. Catalogue of the ground-beetles of Bulgaria (Coleoptera: Carabidae). Sofia-Moscow: Pensoft. 279 p.

Henwood W.D. 2010. Toward a strategy for the conservation and protection of the world's temperate grasslands. Great Plains Research 20: 121-134.

Hieke F., Wrase D.W. 1988. Faunistik der Laufkafer Bulgariens (Coleoptera, Carabidae). Deutsche Entomologische Zeitschrift 35: 1-171.

Ile G.A., Maier A.R.M., Cadar A.M., Covaciu-Marcov S.D., Ferenți S. 2020. Dead snakes and their stories: morphological anomalies, asymmetries and scars of road killed Dolichophis caspius (Serpentes, Colubridae) from Romania. Herpetozoa 33: 7-85. DOI: 10.3897/ herpetozoa.33.e51338

Ivajnšič D., Devetak D. 2020. GIS-based modelling reveals the fate of antlion habitats in the Deliblato Sands. Scientific Reports 10(1): 5299. DOI: 10.1038/s41598-020-62305-3

Kadyrbekov R.K., Childebaev M.K., Zhdanko A.B., Tleppaeva A.M., Kolov S.V. 2016. Features of fauna and ecology of insects (Insecta) in the steppe zone of
Pavlodar region (Northern Kazakhstan). Selevinia 24: 91-95. [In Russian]

Lie P. 1995. Beiträge zur Kenntnis des Carabus hungaricus frivaldskyanus Breuning neuentdeckt im Banat, Rumänien (Coleoptera, Carabidae). Folia Entomologica Hungarica 56: 85-88.

Lie P. 1996. Carabus (Pachystus) hungaricus frivaldskyanus Breuning 1933, a sure presence in the Romanian fauna (Coleoptera: Carabidae). Buletinul de Informare Entomologică al Societăţi Lepidopeterologice Române 7(1-2): 147-149.

Magyari E.K., Chapman J.C., Passemore D.G., Allen J.R.M., Huntley J.P., Huntley B. 2010. Holocene Persistence of wooded steppe in the Great Hungarian Plain. Journal of Biogeography 37(5): 915-935. DOI: 10.1111/j.1365-2699.2009.02261.x

Noordijk J., Prins D., de Jonge M., Vermeulen R. 2006. Impact of road an the movements of two ground beetle specie (Coleoptera: Carabidae). Entomologica Fennica 17: 276-283. DOI: 10.33338/ef.84346

Panin S. 1955. Familia Carabidae (gen. Cyhrus şi gen. Carabus), Fauna Republicii Populare Române, Insecta. Vol. 10(2). Bucureşti: Editura Academiei. 148 p.

Podluka P., Hauck D., Cizek L. 2012. Importance of marginal habitats for grassland diversity: fallows and overgrown tall-grass steppe as key habitats of endangered ground-beetle Carabus hungaricus. Insect Conservation and Diversity 5(1): 27-36. DOI: 10.1111/j.17524598.2011.00146.x

Popescu I.E., Iorgu I.Ș. 2016. The Second Confirmed Station for Carabus hungaricus (Fabricius, 1792) (Coleoptera: Carabidae) in Romania. Travaux du Muséum National d'Histoire Naturelle «Grigore Antipa» 59(1): 81-84. DOI: 10.1515/travmu-2016-0018

Putchkov O.V. 2009. The Hungarian ground beetle, Carabus (Pachystus) hungaricus (Fabricius, 1792). In: I.A. Akimova (Ed.): Red Data Book of Ukraine. Fauna. Kiev: Global Consulting. P. 94. [In Ukrainian]

Putchkov A.V., Brygadyrenko V.V., Markina T.Y. 2019. Ground beetles of the tribe Carabini (Coleoptera, Carabidae) in the main Megapolises of Ukraine. Vestnik Zoologii 53(1): 3-12. DOI: 10.2478/vzoo-2019-0001

Sala O.E., Chapin F.S., Armesto J.J., Berlow E., Bloomfield J., Dirzo R., Huber-Sanwald E., Huenneke L.F., Jackson R.B., Kinzig A., Leemans R., Lodge D.M., Mooney H.A., Oesterheld M., LeRoy Poff N., Sykes M.T., Walker B.H., Walker M., Wall D.H. 2000. Global Biodiversity Scenarios for the Year 2100. Science 287(5459): 1770-1774. DOI: 10.1126/science.287.5459.1770

Sas-Kovács É.H., Sas-Kovács I., Urák I. 2015. Alopecosa psammophila Buchar, 2001 (Araneae: Lycosidae): morphometric data and first record for Romania. Turkish Journal of Zoology 39(2): 352-358. DOI: 10.3906/zoo-1404-11

Szatmari P.M. 2015. Additional Glacial Relicts in Carei Plain natural protected area, north-western Romania. Acta Horti Botanici Bucurestiensis 42: 23-40. DOI: 10.1515/ ahbb-2015-0003

Szél G., Bérces S., Kutasi C., Kodobocz V. 2006. A magyar futrinka (Carabus hungaricus Fabricius, 1792) hazai 
elterjedése és élõhelyei. Praenorica Folia HistoricoNaturalia 9: 45-80.

Teodor L.A., Ferenți S., Covaciu-Marcov S.D. 2019. Weevils die in Vain? Understanding Messages from Road-Killed Weevils (Coleoptera: Curculionoidea). Coleopterists Bulletin 73(2): 359-368. DOI: 10.1649/0010-065X-73.2.359

Turin H., Penev L., Casale A., Arndt E., Assmann T., Makarov K., Mossakowski D., Szél G., Weber F. 2003. Chapter
5. Species accounts. In: H. Turin, L. Penev, A. Casale (Eds.): The Genus Carabus in Europe. A Synthesis. Fauna Europaea Nevertebrata 2. Sofia and Moscow: Pensoft. P. 151-285.

Yamada Y., Sasaki H., Harauchi Y. 2010. Effects of narrow roads on the movement of carabid beetles (Coleoptera, Carabidae) in Nopporo Forest Park, Hokkaido. Journal of Insect Conservation 14(2): 151-157. DOI: 10.1007/ s10841-009-9236-z

\title{
ПОГИБШИЕ НА ДОРОГАХ ЖУЖЕЛИЦЫ ПОДТВЕРЖДАЮТ НАЛИЧИЕ CARABUS HUNGARICUS (COLEOPTERA: CARABIDAE) НА СЕВЕРО-ЗАПАДЕ РУМЫНИИ
}

\author{
А. Ш. Чикорт-Лукачиу \\ Университет Орадя, Румыния \\ e-mail: cicort.alfred@yahoo.com
}

Равнина Карей является особо охраняемой природной территорией (ООПТ) на северо-западе Румынии. Она отличается высоким биоразнообразием, которому, помимо прочих антропогенных факторов, угрожает наличие движения на дорогах. Уровень смертности на дорогах и ее последствия были отмечены на территории исследования некоторыми другими данными. В ходе исследования смертности на дорогах в 2016 г. мы обнаружили пять особей Carabus hungaricus, погибших на дорогах. Этот вид является редким в Румынии. Равнина Карей расположена в нескольких километрах от местонахождения данного вида в Венгрии. Дорога окружена песчаными дюнами и влажными участками с богатой травянистой растительностью, а также с посадками Robinia pseudoacacia. Carabus hungaricus - peдкий вид, имеющий зоогеографическое и природоохранное значение. Фактическое распространение C. hungaricus на территории исследования должно быть установлено путем изучения потенциальных местообитаний вида на данной ООПТ.

Ключевые слова: местообитание, равнина Карей, распространение, сенокосно-пастбищное угодье, ООПТ, смертность на дорогах 